\title{
都心回帰下の首都圈における住環境のイメージの空間構造とその遷移 SPACIAL STRUCTURE AND TRANSITION OF THE REGIONAL IMAGES WITHIN THE TOKYO METROPOLITAN AREA IN THE ERA OF URBAN CORE REVIVAL
}

\author{
吉江 俊*, 後藤春彦** \\ Shun YOSHIE and Haruhiko GOTO
}

\begin{abstract}
Since the Japanese housing system was marketed at the end of the 20th century, a huge amount of private sale housings were built and became a receiver for the people who returned to the metropolitan area. As more than 20 years have passed since the arrival of the era of urban core revival, it is indispensable to analyze images of lifestyles seen in the housing market to read changes in the living environment.

The purpose of this paper is to clarify how residential housing has changed the living environment by analyzing expressions of housing advertisement. There are three investigations:

1) Location and value change of private sale housing under the era of urban core revival

2) Transition of the regional image caused by soaring and falling of residential land prices

3) Actual state of the areas that achieved transitions of unique regional images
\end{abstract}

Keywords: Tokyo metropolitan area, Private Condominium, Regional Image, Housing advertisement, Spatial structure 首都圈, 民間分譲住宅, 地域像, 住宅広告, 空間構造

\section{1 章 緒言}

\section{1-1 研究の背景と目的}

人口の都心回帰が叫ばれて約 20 年が経過した首都圈では、住宅地 価の高騰・下落の格差化や新旧住民間の摩擦など様々な問題が顕在

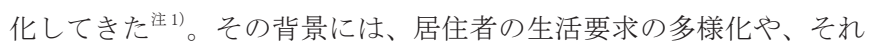
に伴い市場で取引される住宅価值の高次化、イメージ的な欲望を満 足する性能一の移行などの、住環境の消費化が挙げられる。

我が国が高度経済成長を遂げつつある 1960 年代末には、画一的な 住宅ではなく個性的な「私のための家」を持ちたいという「マイホー ム主義」が流行したことがすでに注目されている ${ }^{2)}$ 。1970 年代末に なると第四次マンションブームとともに民間事業者の参入が顕著に なり、1980 年代末には、住宅の価值が使用価值から交換価值や記号 価值に重点を移していったとする住宅の消費化が議論された ${ }^{3)}$ 。こう した住宅価值の消費化を主題とする実証的研究は殆ど行われてこな かったが、都心居住の実態調査を通じてその片鱗は報告されてきた注 2)。90 年代半ばからは新自由主義の政策再編とともに住宅システムは 市場化され注3)、21 世紀の住環境を理解するうえで住宅市場に流通す るイメージ的価值の理解が不可欠になったといえよう。

これらに対して、筆者は住宅価値が (1)イメージへと展開したこと、 (2)「いえ」そのものだけでなく「まち」へと展開して取引されるよ
うになったことを指摘し、研究を進めてきた。成果として、住宅市 場に供給される住環境の価值イメージの実態 ${ }^{7)} や 、$ 生活者が抱く住 環境に関する欲求の分析 ${ }^{8)}$ を経て、約 100 種のイメージ的指標に基 づく首都圈の住宅選好原理が明らかになっている。

本稿では以上の知見を都市空間へ展開し、住宅広告に表れる住宅 地の環境に関する語りの地理的分析を行う。地域像の変化をはじめ て首都圏レベルの空間スケールで可視化して捉えることで、住環境 の消費化・多様化の実態を俯瞰し、地理に根差した具体的な議論に 資する知見を得ることを目的とする。具体的には都心回帰下の首都 圈（一都三県）に照準し、以下の 3 点を明らかにする：

1）都心回帰下における民間分譲住宅の立地および価值変化

2）住宅地価高騰・下落とともに生じる地域像の遷移

3）特異な地域像の遷移を遂げる地域の実態

\section{1-2 研究の位置づけ}

本研究は住宅地の環境評価と圈域性に関する研究と、都市イメー ジの研究の両者に跨るものである。前者の位置づけは既報にて示し た通りであるので注4)、本稿では後者の位置づけを整理した。

Fig.1 (次頁)に示したように、都市イメージ研究は主としてヒア リングやアンケート調查を通した認知イメージの研究と、様々なメ ディアに表れる表象イメージの研究に分けられる。また分析的観点

\footnotetext{
* 早稲田大学大学院創造理工学研究科 博士課程 - 修士(建築学)

** 早稲田大学理工学術院 教授・工博 


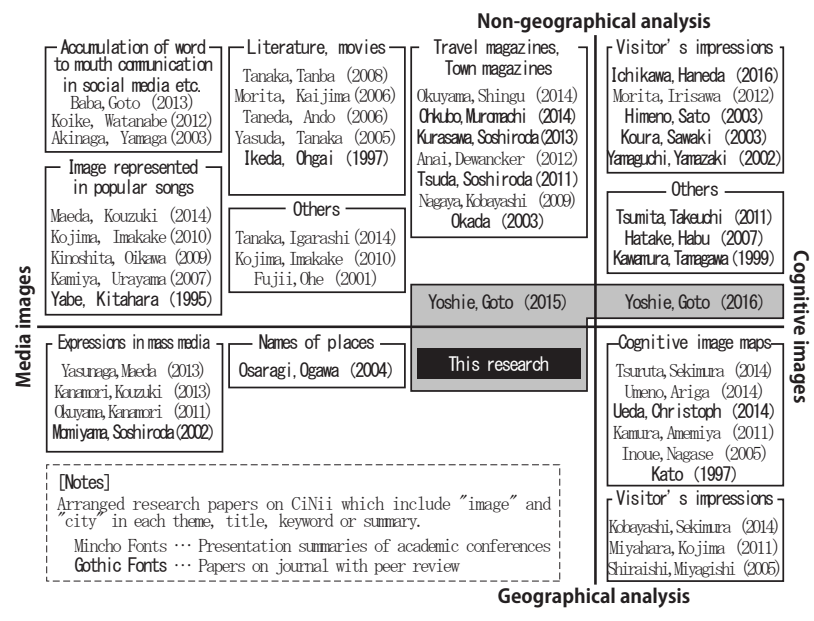

Fig. 1 Position of this research in domestic research of urban image

からは、実際の都市空間での広がりを議論する即地的研究と、心象 に留まる非即地的研究に分けられる。

当分野では、表象イメージの即地的分析が殆ど行われてこなかっ たのが特徴的である。倉澤ら ${ }^{9)}$ や津田ら ${ }^{10)}$ は旅行雑誌から観光地の イメージの内容を分析しているが、空間性よりもまち全体のイメー ジの意味構成を描き出すことを目的としている。一方大佛ら ${ }^{11)}$ はマ ンション名に含まれる地名の広がりを分析し、その広がりから地域 の魅力の強さを論じているが、魅力の内容そのものには迫っていな い。粐山ら ${ }^{12)}$ は都市情報誌から 13 の繁華街における 1988-2001 年 間のイメージ変遷を追い、繁華街間のイメージの連帯を論じたが、 首都圈の全体像を描き出す精度を有してはいない。

以上を踏まえると、本研究は (1) 表象イメージの即地的研究の中 でもはじめて住環境に照準する研究であり、(2) 首都圈全体のスケー ルでその変化を可視化する方法をとる点に独自性を有する。

\section{1-3 研究の方法}

本研究では都心回帰下における住宅地価の高騰・下落とともに生 じる住環境のイメージ変化やライフスタイルの変化を明らかにする。 2 章で分析対象の二時代を設定したのち、以下の通りに分析を進める。

3 章では住宅広告を資料に用いて首都圈（本稿では一都三県）の 民間分譲住宅の価格・広さ・階数および立地の統計的な概観を行う。 これにより、二時代の主な民間分譲住宅の特性を抽出・比較する。 4 章では住環境価值の種類を駅圈単位で集計し、その組み合わせによっ て空間を類型化することで「地域像」の類型を得る。続いて「地価 公示資料」より住宅地価の変化を把握し、地価高騰・下落とともに 生じる地域像変化の傾向を把握する。5 章では特異な地域像の变化を 遂げた地域に注目し、物理的な住環境の変容と合わせて地域変化を より詳細に論じる。6 章では以上の研究成果を総括する。

\section{2 章 都心回帰下の住環境変化を捉えるための比較基準時点の設定}

\section{2-1 2015 年に対する比較基準時点の設定}

本稿では都心回帰下の住環境イメージ変化を捉えるために、把握 可能な最新年である 2015 年と、人口の都心回帰とともに民間の住宅 供給が安定し始めた 2000 年の 2 点を比較時点として設定する。

バブル経済崩壊以来住宅着工数は減少を始めたが、再び増加に転 じた 1994 年前後を期に、人口の都心回帰が注目され始めた。95-00 年の第七期住宅建設五箇年計画では都市居住が中心テーマとなり、
この時期に第六次マンションブームが生じている ${ }^{13)}$ 。99 年の都市基 盤整備公団の分譲からの撤退、00 年の定期借家制度の導入、03 年の 住宅金融公庫の廃止など公共による住宅供給が減退し、民間による 住宅供給が安定し始めたのが 2000 年前後であると言える ${ }^{\text {注5)。 }}$

\section{2-2 建て方および建築主の変化からみる民間分譲住宅の位置づけ}

Fig. 2 に、建て方別にみた東京都の住宅着工数を示した。本図から、 バブル経済期では貸家の着工が多くを占めていたが、1998 年以降に は分譲住宅が急増し多くを占めるようになったことが分かる。続い て建築主別に住宅着工数を集計すると（Fig. 3)、以前は個人を建築 主とする住宅の着工が多くを占めていたが、98 年以降会社を建築主 とする民間住宅が多くを占めるようになったことが分かる。以上の 結果から、2000 年以来の人口の都心回帰を主に担った新築住宅の多 くは、民間の分譲住宅であったことが分かる。

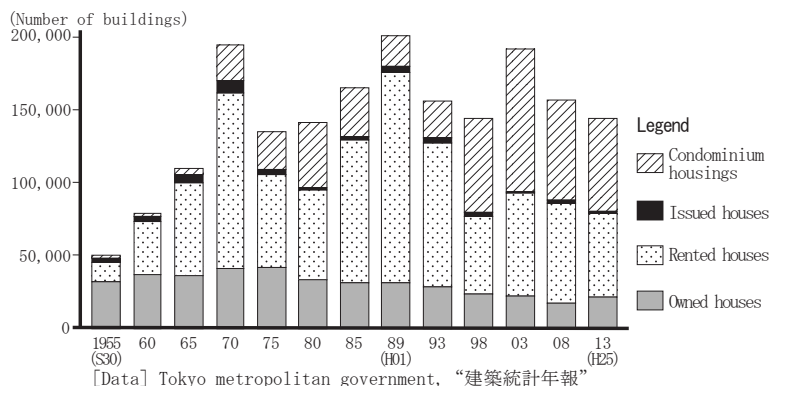

Fig. 2 Built houses in Tokyo by tenure

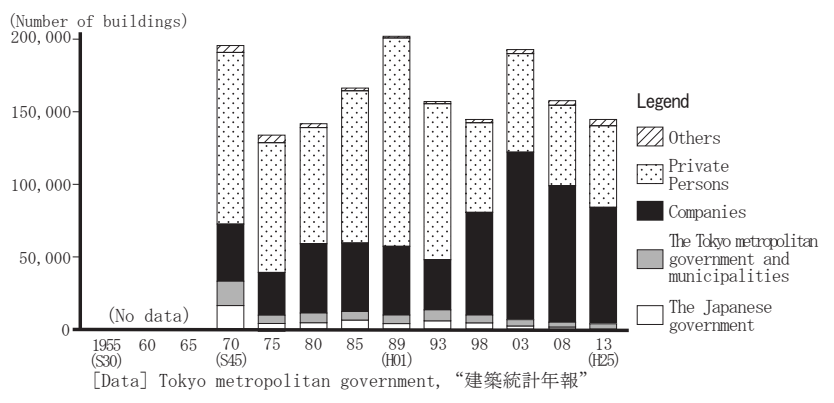

Fig. 3 Built houses in Tokyo by owners

\section{2-3 対象資料の概要}

先の考察を受けて、本稿では民間の分譲住宅を対象に設定し、そ れらの住宅広告に描かれる住宅や立地地域の価值イメージを分析す る。資料は筆者の既報と同様に、2000 年に売り出された民間分譲住 宅の住宅広告の資料としてリクルート出版『週刊住宅情報 首都圈 版』2000 年発行巻を、2015 年の住宅広告の資料として同社『SUUMO 新築マンション 首都圈版』 2015 年発行巻を利用し、それぞれ 1 月、 4 月、 7 月、10 月の初週号に掲載されている一都三県に立地するすべ ての民間分譲住宅を対象とした注6)。2000 年売り出しの対象は 768 件、 2015 年の対象は 403 件であった。

\section{3 章 都心回帰下における民間分譲住宅の立地および価値変化}

本章では先述の資料を用いて、2000 年、2015 年それぞれに供給さ れた民間分譲住宅の基本的な特性を把握したのち、各住宅での暮ら しにおいて享受できるとされる住環境価值の差異を明らかにする。

\section{3-1 価格、広さ、階数の関係変化}

Fig. 4 に二時代における対象住宅の階数の比率を示した注7)。図 中では、10\%を超える項目を点線で囲んで示している。本図から、 
2000 年には 1-15 階建ての住宅が多数を占めていたが、2015 年には 低層の住宅の比率が減少し 6-15 階建てが多くを占めていることが分 かる。また 31 階建て以上の住宅も微増していることが把握できる。

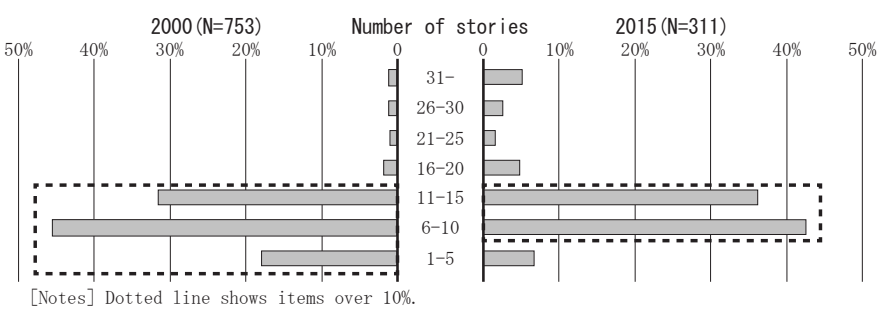

Fig. 4 Change in number of stories 2000-2015

Fig. 5 に二時代における平均分譲価格の比率を示した。本図から、 2000 年では 3 千万円から 6 千万円台の住宅が多数を占めているが、 2015 年には高額の住宅の比率が減少し 3 千万円から 5 千万円台の範 囲の住宅が多くを占めるようになったことが把握できる。

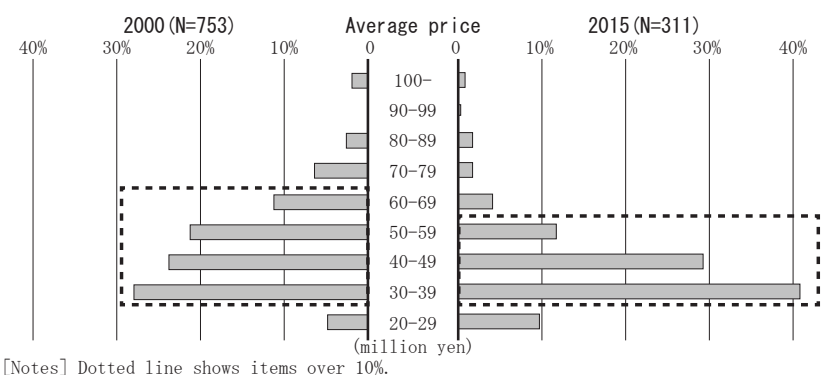

Fig. 5 Change of average prices 2000-2015

Fig. 6 に二時代における対象住宅の、物件ごとの平均専有面積の比 率を示した。2000 年と 2015 年では共通して $60 \mathrm{~m}^{2}$ から $80 \mathrm{~m}^{2}$ 台の住宅 が多くを占めていることが分かるが、前者では $70 \mathrm{~m}^{2}$ 台の住宅が突出 して多いことが把握できる。

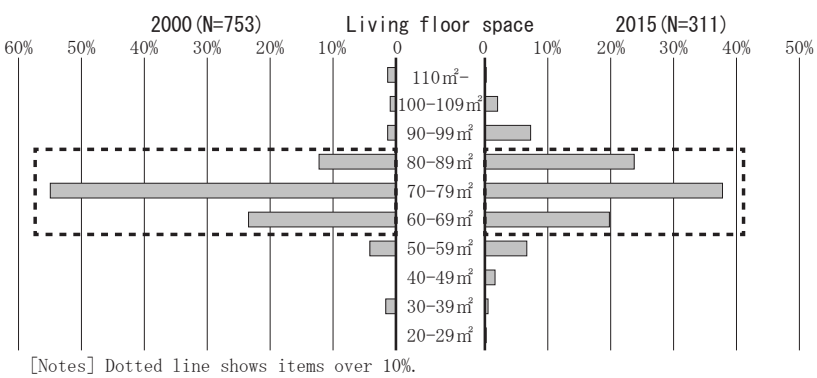

Fig. 6 Change of living floor spaces during 2000-2015

以上のように、首都圈に供給される民間分譲住宅は階数・価格 · 平米数ともに、全体のうち一部の範囲に収まるものが多数を占めて いることが明らかになった。この多数を占める住宅が、都心回帰下 の首都圈に供給された主な民間分譲住宅と考えられるので、その範 囲を前節の考察（Fig. 4, 5, 6 点線部）を根拠に図中に示すと Fig. 7 が 得られる。住宅全体の範囲は価格・階数ともに拡大しているが (白色)、 多数を占める住宅の範囲は反対にやや縮小していることが分かる（灰 色)。これらの多数を占める住宅を、本稿では「標準民間分譲住宅」 と呼ぶこととする。

\section{3-2 標準／非標準民間分譲住宅の立地変化}

標準民間分譲住宅とそれ以外の住宅（便宜上、非標準民間分譲住 宅と呼ぶ）の分布傾向を把握するために、Fig. 8 に二時代の民間分譲 住宅の分布を示した。2000 年の標準民間分譲住宅は東京駅を中心と

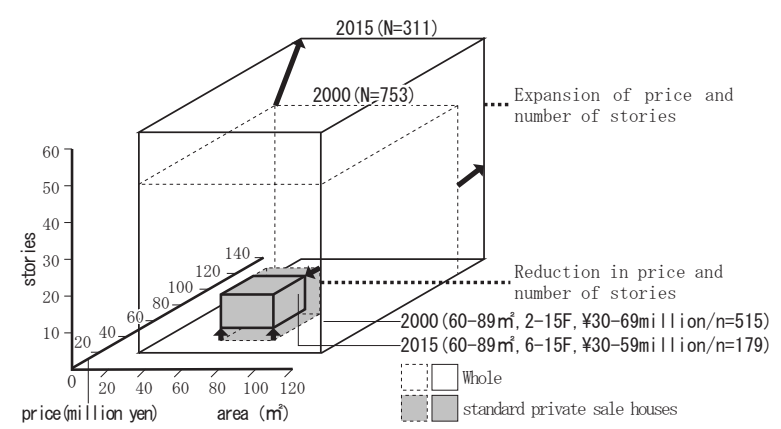

Fig. 7 Change of standard private sale housing 2000-2015

した $40 \mathrm{~km}$ 圈の全体に供給されているが、2015 年になると中心部に縮 退し、特に横須賀方面の減少が際立っている。一方で非標準民間分 譲住宅は山手線沿線を中心に放射状に分布しており、中央線、田園 都市線、東海道本線、京葉線などの路線を際立たせている。2015 年 には放射状の分布構造を残しながらも東京都区部に際立った集積を みせ、中央区・港区を中心に高層化している様子が見て取れる。

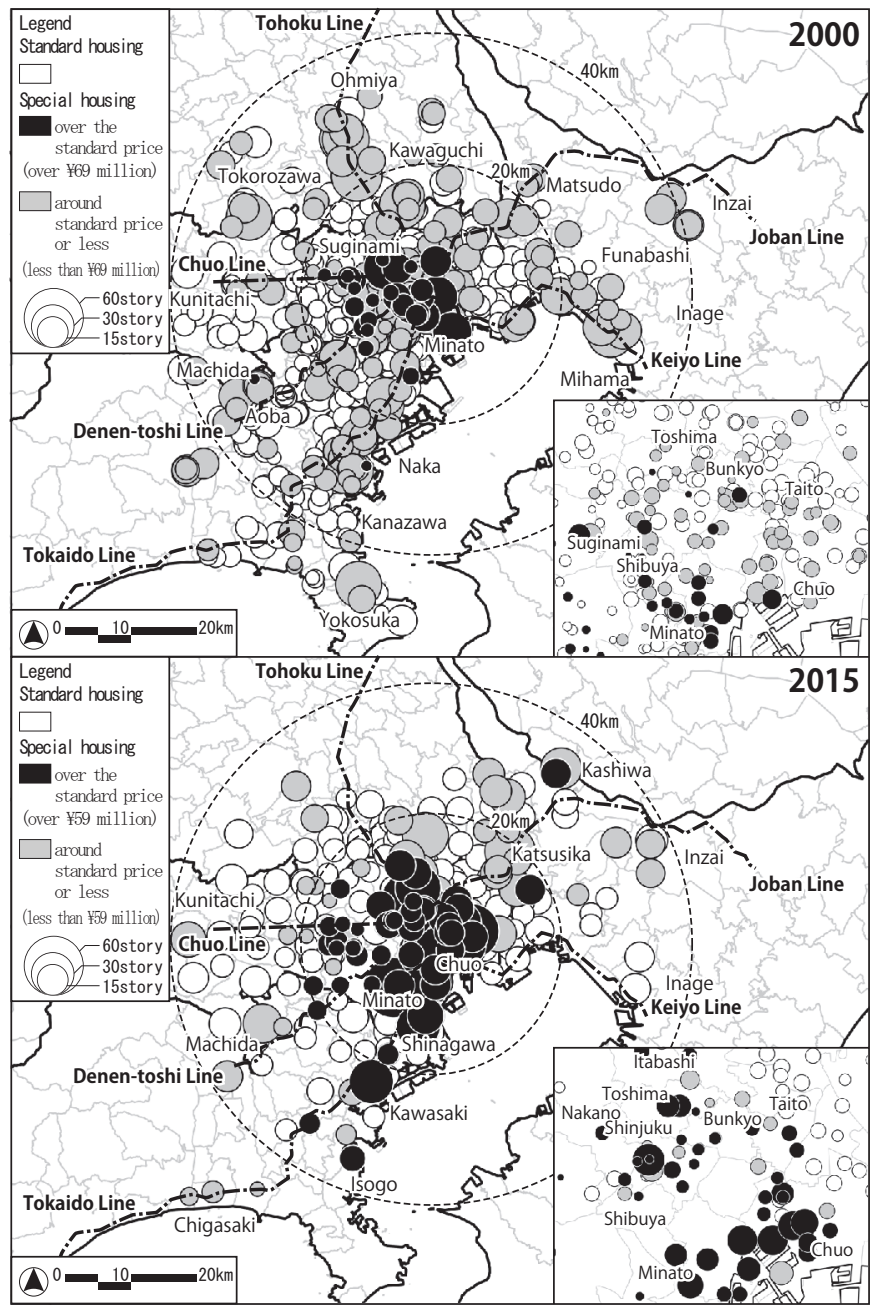

Fig. 8 Distribution of standard/special private sale housing

\section{3-3 標準/非標準民間分譲住宅の謳う住環境価値の変化}

次に、これらの住宅で居住者が享受できるとされる住環境価值の 内容を明らかにする。同様の資料の売り文句において表現される住 環境に関する語りを、その意味が多義的にならない最小表現に分割 して抽出し分類した（Tab1e1、次頁）。2000 年では 9085 サンプル、 2015 年では 5953 サンプルが抽出でき、これらを既報の枠組みである 
「住居の価值」「立地地域の価值」に沿って整理した。

Table1 Classification of values in living environment a.Values of home

$\begin{array}{lll}\text { Nature 1. Water view 2. Green area 3. View of sky and sunshine } 4 \text {. Four seasons } & \end{array}$

Function 5.Vista 6. Hospitality 7.Sports, health 8.Shared space 9.Privacy 10 .Pet oming 11. Size 12. Costs 13. Hobby 14. Energy efficiency 15. Flexibility 16. Internal corridor 17. Fresh air 18.Strolling opportunities $\quad$ 19. Comfort 20. Functionality 21. Security 22. Quake-resistance 23. Storage 24.Cooking

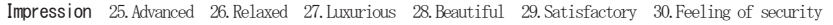
31. Feeling of opening 32. Fashionable 33. Hotellike 34. Japanese style 35. Landmark 36. Multifaceted 37. Nestern 38. Longing 39. Family 40. Self-expression 41. Sense of daily life 42. Sense of being Active 43. Permanent home 44. Mbdem 45. Apealing to Ilomen 46. Feeling of detached house 47. Friendly to elder people 48. Others

\section{b.Values of surrounding environment}

Nature 49. Water view 50. Green area 51. View of sky and sunshine 52. Four season

Function 53. Shopping 54. Eating 55. Entertainment 56. Public facility $\quad$ 57. School 58. Park 59. Sports, health 60. Strolling opportunities 61. Accessibility 62. On the hillside 63. Level ground Impression 64. Advanced, urban 65. Peaceful 66. Luxurious 67. Beautiful 68. Mature 69. Feeling of security 70. Open 71. Trendy 72. Bustling 73. Cultural 74. Domntown 75. Western 76. Longing 77. Child rearing

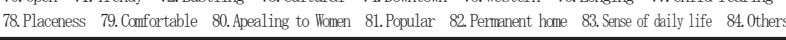

\section{1）居住者が享受できるとされる住居に関する価値の変化}

住居に関する価伹の変化をFig. 9 に示した。図では、住居に関する 住環境価值の該当率が $20 \%$ 以上の項目を表示しており、2000 年の標 準民間分譲住宅の価値の項目を基準として変化した項目を灰色で示 している。首都圈全域に分布する標準民間分譲住宅住宅では、2000 年において 20, 機能性、3. 空 ・日光、26. ゆとり・憩いなどの基本 的な価値が中心であったが、2015 年には 39. 家族、12. コストなど が増えている。標準民間分譲住宅と比較すると非標準民間分譲住宅 の価值の違いは 2000 年には顕著に見られないが、2015 年には 39. 家 族、11. 広さ、28. 風情・美、29. 質・満足感などが加わってより多 様な印象的価值を含むものとなっている。

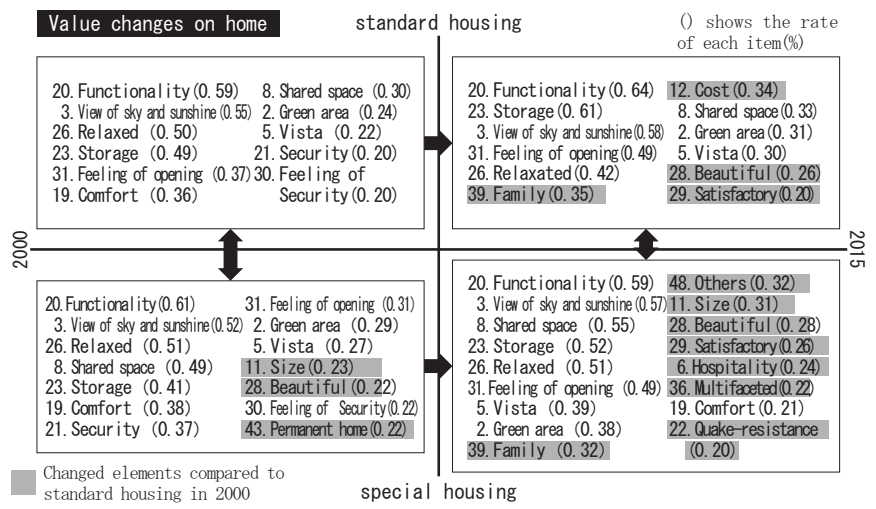

Fig. 9 Value changes on home

\section{2）居住者が享受できるとされる立地地域に関する価値の変化}

同様の方法で、立地地域に関する価值の変化をFig. 10 に示した。 2000 年の標準民間分譲住宅においては61. 利便性、53。買い物、

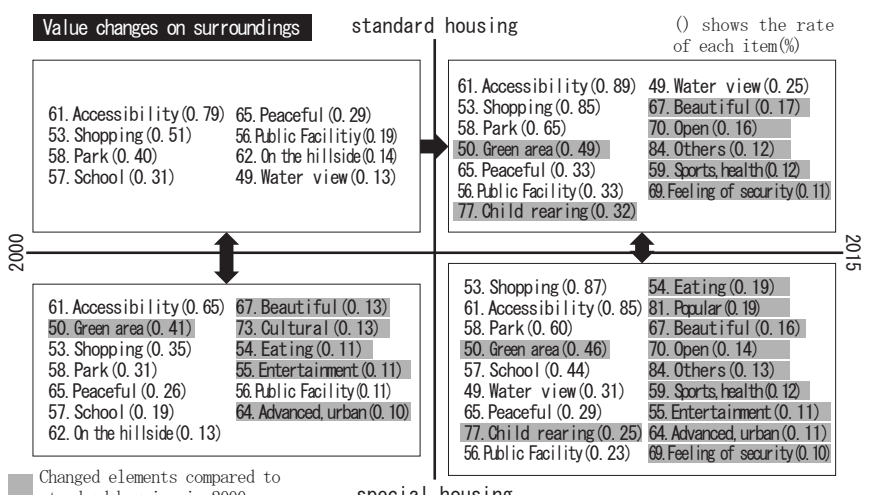

Fig. 10 Value changes on surrounding environment
58. 公園など機能的な価值の享受に留まっていたが、2015 年には 50。緑、77. 子育て、67。風情・美などより多くの価值が出現している。 他方で非標準民間分譲住宅は、2000 年から印象的価值をいくつか含 んでいたが、2015 年には 81. 注目・話題性、70. 開放感などのより 多様な印象的価值を享受できるとされるようになっている。

\section{3-4 小結 : 都心回帰下の民間分譲住宅の二重構造}

本章で明らかになった知見を整理すると Fig.11が得られる。都心 回帰下の民間分譲住宅には多様な価格、広さ、規模のものが供給さ れてきたが、多くはその多様性の中でもある狭い範域に収まること が明らかになった。この範域に収まる住宅を標準民間分譲住宅と呼 ぶと、そうでない住宅（非標準民間分讓住宅）との間に明らかな分 布特性の差異があることが確認された。最後に住環境価值をみると、 標準民間分譲住宅は基本的な価值の享受に留まるのに対し、非標準 民間分譲住宅はより多様でイメージ的な価值の享受を謳っているこ とが明らかになった。以上のように都心回帰下の民間分譲住宅には、

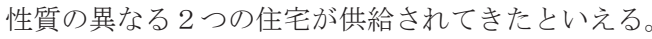

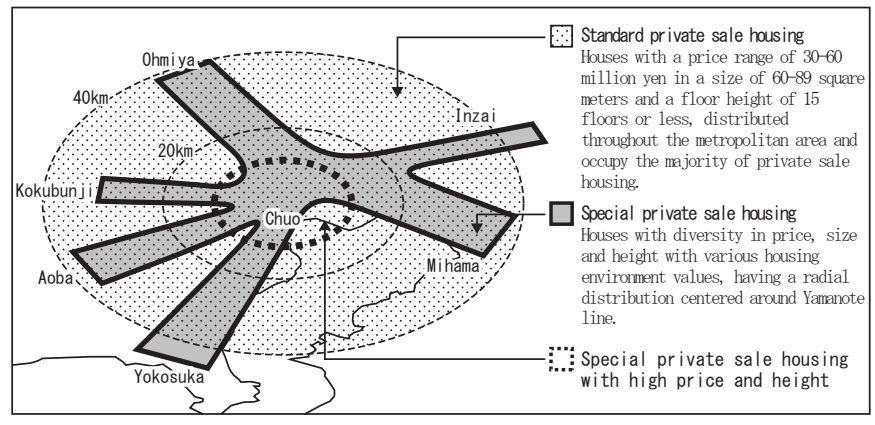

Fig. 11 Distribution of standard/special private sale housings(surmary)

\section{4 章 住宅地価高騰・下落とともに生じる地域像の遷移}

本章では民間分譲住宅の広告中にどのような立地地域の価值が描 かれてきたかを、駅圈単位で集計して分析する。この結果を地価が 高騰・下落している地域と重祇合わせることで、地価変動とともに 生じる地域像の変化について論じる。

\section{4-1 駅圏単位の住環境価值の構成比による地域像のクラスタ分析}

国土交通省国土政策局国土情報課が公開している、2015 年時点で 営業している駅の座標を用いてボロノイ図を作図し、各図形を駅圈 と呼ぶ注8)。住環境価值のうち立地地域に関する価值の該当の有無を 0,1 に変換し、住所と紐づけて地理情報システム（GIS）でプロット して駅圏単位で集計した。立地地域の価值が 3 つ上集計された駅 圈は、2000 年で $384 、 2015$ 年で 212 あった注 9)。

続いて駅圈単位で集計した立地地域の価值の構成を類型化する。 2000 年、2015 年で一貫した類型を得るために、先に得られた合計 596 の駅圈を二時点で分けずに対象として、立地地域の価值の有無の 集計数をパラメータとするクラスタ分析（ウォード法、ユークリッ ド距離）を行い、距離の開いた地点でデンドログラムを切断し 60 の類型を得た（Fig. 12、次頁）。

Tab1e2（次頁）に、各類型の内容の特化係数を示した。6つのクラ スタの内容構成のうち、とくに特化係数の高い項目を踏まえて、各 類型を「CL1 生活施設欠如低利便地域」「CL2 教育・安心感特化地域」 「CL3 自然価值欠如低イメージ地域」「CL4 高台永住地域」「CL5 歓楽 洗練都会地域」「CL6 高度イメージ包含地域」と命名した。れれは住宅の 
Table2 Values constituting the six regional image clusters

\begin{tabular}{|c|c|c|c|c|c|c|c|c|c|c|c|c|c|c|c|c|c|c|c|c|c|c|c|c|c|c|c|c|c|c|c|c|c|c|c|c|c|}
\hline \multirow[b]{2}{*}{$\mathrm{CL}$} & \multirow[b]{2}{*}{ 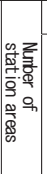 } & \multicolumn{4}{|c|}{ Nature } & \multicolumn{11}{|c|}{ Function } & \multicolumn{21}{|c|}{ Impression } \\
\hline & & 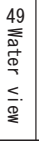 & 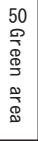 & 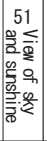 & 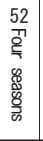 & 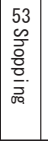 & 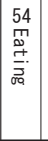 & 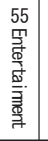 & 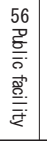 & 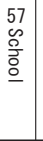 & $\begin{array}{l}58 \\
\mathbb{0} \\
\stackrel{ \pm}{x} \\
\end{array}$ & 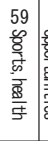 & 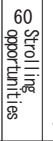 & 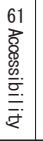 & 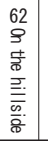 & 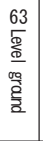 & 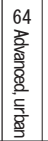 & $\begin{array}{l}65 \\
\mathbb{D} \\
\mathbb{J} \\
\mathbb{D} \\
\mathbb{\Phi} \\
\underline{\underline{D}}\end{array}$ & $\begin{array}{l}66 \\
\frac{66}{5} \\
\frac{5}{5} \\
\frac{8}{\infty}\end{array}$ & 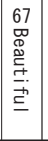 & 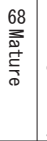 & 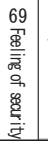 & \begin{tabular}{|c|}
70 \\
$\stackrel{0}{0}$ \\
$\stackrel{9}{9}$ \\
\end{tabular} & $\mid \begin{array}{l}71 \\
\overrightarrow{1} \\
\mathbb{0} \\
\overrightarrow{2} \\
2\end{array}$ & 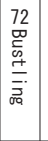 & 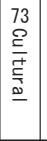 & 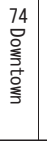 & 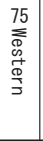 & 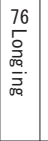 & 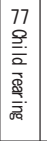 & 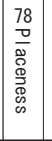 & 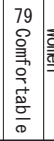 & 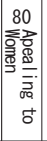 & 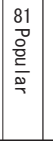 & 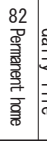 & 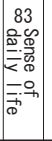 & $\begin{array}{l}84 \\
\text { o } \\
\text { 高 } \\
\frac{\text { के }}{\omega} \\
\text { s }\end{array}$ \\
\hline $\begin{array}{ll}\mathrm{CL} 1 \\
\end{array}$ & 85 & 0.33 & 0.61 & 0.55 & 0.12 & \begin{tabular}{|l|}
0.07 \\
\end{tabular} & \begin{tabular}{|l|}
0.17 \\
\end{tabular} & 0.35 & 0.09 & 0.06 & 0.55 & 0.36 & 0.54 & 0.42 & 0.75 & 0.16 & 0.50 & 0.63( & 0.29 & 0.35 & 0.76 & 1.11 & \begin{tabular}{|l|}
0.38 \\
\end{tabular} & 0.40 & \begin{tabular}{|l|}
0.27 \\
\end{tabular} & \begin{tabular}{|l|}
1.07 \\
\end{tabular} & \begin{tabular}{|l|}
1.47 \\
\end{tabular} & 1.33 & 0.86 & \begin{tabular}{|l|}
0.18 \\
\end{tabular} & 0.59 & 0.37 & & 0.32 & 1.85 & 0.63 & 0.20 \\
\hline $\mathrm{CL2}$ & 105 & 0.70 & 1.17 & 1.10 & 1.43 & 1.31 & 0.94 & 0.73 & 1.99 & 1.93 & 1.33 & 1.25 & 1.09 & 0.98 & 0.69 & 1.30 & 0.48 & 1.32 & 0.47 & 0.78 & 1.38 & 2.19 & \begin{tabular}{|l|}
0.77 \\
\end{tabular} & 0.28 & 1.24 & 0.75 & 1.19 & 0.43 & \begin{tabular}{|l|}
0.70 \\
\end{tabular} & 1.49 & 1.25 & \begin{tabular}{|l|l|l|l|l|}
0.89 & 1
\end{tabular} & 1.25 & 0.67 & 1.25 & 1.18 & 0.78 \\
\hline CL3 & 208 & 0.25 & 0.25 & 0.30 & 0.22 & 0.56 & 0.46 & 0.35 & 0.70 & 0.63 & 0.41 & 0.37 & 0.26 & 0.44 & 0.17 & 0.33 & 0.49 & 0.29 & 0.24 & 0.25 & 0.08 & 0.55 & 0.36 & 0.42 & 0.29 & 0.30 & 2.41 & 0.44 & 0.59 & 0.36 & 0.29 & \begin{tabular}{|l|l|}
0.33 & 1 \\
\end{tabular} & 1.47 & 0.42 & 0.50 & 0.51 & 0.29 \\
\hline CL4 & 136 & 0.16 & 0.84 & 0.63 & $\mid 0.70$ & $|0.61|$ & 0.43 & \begin{tabular}{|l|l|}
1.07 \\
\end{tabular} & 0.56 & 0.77 & 0.74 & 0.34 & 0.64 & 0.66 & 1. 62 & 0.50 & 0.37 & 1.26 & \begin{tabular}{|l|}
0.37 \\
\end{tabular} & 0.49 & 0.71 & 0.46 & 0.45 & 0.32 & 1.01 & 0.94 & 0.92 & 1.17 & 1.62 & 0.46 & 1.33 & \begin{tabular}{|l|}
0.78 \\
\end{tabular} & & 0.28 & 1.74 & 0.65 & 0.57 \\
\hline CL5 & 40 & 1.57 & 0.85 & 0.97 & 1.50 & 1.13 & 1.65 & 2.14 & 0.55 & 0.42 & 0.74 & \begin{tabular}{|l|}
0.87 \\
\end{tabular} & 1.05 & 1.16 & 0.30 & & 2.04 & 0.58 . & 1.24 & 1.06 & 1.61 & 0.26 & 0.26 & 1.47 & 2.49 & 1.24 & & 0.57 & & 0.81 & 0.25 & 1.093 & 3. 28 & 1.09 & 0.66 & 2.22 & 2.40 \\
\hline $\mathrm{CL} 6$ & 22 & 299 & 2.29 & 2.46 & 204 & 231 & 2.34 & 1.36 & 2.10 & 220 & 2.23 & 2.81 & 2.42 & 234 & 2.47 & 0.33 & 2.12 & 1.92 & 3.39 & 3.06 & 1.46 & 1.43 & 3. 39 & 3.11 & 0.70 & 1.69 & & 206 & 2.23 & 2.71 & 229 & 255 & & 3.22 & & 0.81 & 2.75 \\
\hline
\end{tabular}

周辺地域に対する価值イメージの集合の類型であるから、以下本稿ではこれ らを地域像の類型と呼ぶ。それぞれの特徵はTable3に示すとおりである。

\section{4-2 6 つの地域像の地理的分布とその動態}

6 つの地域像の類型別に、該当する駅圏を Fig. 13 に可視化した ${ }^{\text {i: }}{ }^{10)}$ 。

「CL1 生活施設欠如低利便地域」は 2000 年に多く 2015 年には大幅

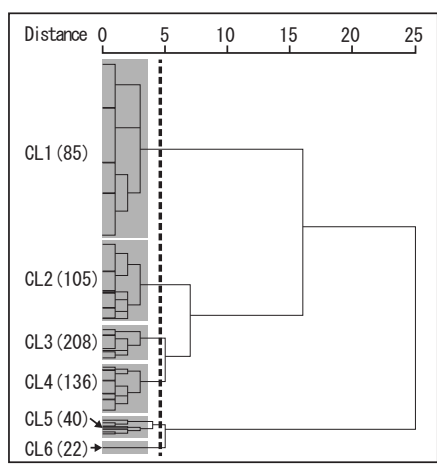

Fig. 12 Dendrogram of cluster analysis
に減少している。2000 年には

都心中心部から神奈川方面に 向かって分布する傾向にあっ たが、2015 年には一転し中心 部に散在しており、二時点で 継続している地域は元町・中 華街の 1 地域だけであった。

「CL2 教育・安心感特化地 域」は 2000 年、 2015 年間で 微増している。2000 年には都 心 $40 \mathrm{~km}$ 圈外を含む郊外地域
Table3 Clusters of regional images and their characteristics Clusters of Regional Images Characteristics

\begin{tabular}{|c|c|}
\hline $\begin{array}{l}\text { a1 Low convenience area with } \\
\text { lacking of living facil lities }\end{array}$ & $\begin{array}{l}\text { Regions with low value ingeses, especially where the value of the living } \\
\text { facility is significantly low }\end{array}$ \\
\hline $\begin{array}{l}\text { Q2 Education / security } \\
\text { special ized area }\end{array}$ & $\begin{array}{l}\text { Regions enjoying an enviromment that is special ized for public, medical, and } \\
\text { educational facilities and have a sense of security }\end{array}$ \\
\hline $\begin{array}{l}\text { Q3 Low imge area with lacking } \\
\text { of enviromental values }\end{array}$ & $\begin{array}{l}\text { Regions with low value images, especially where the value of the nature is } \\
\text { significantly low }\end{array}$ \\
\hline $\begin{array}{l}44 \text { High ground } \\
\text { permanent-living area }\end{array}$ & $\begin{array}{l}\text { Regions enjoying being located on high grounds and enviroment of permenent } \\
\text { living }\end{array}$ \\
\hline $\begin{array}{l}0 \text { Urban area with } \\
\text { entertaimment }\end{array}$ & $\begin{array}{l}\text { Regions that specialize in waterside and enjoy enviroments such as } \\
\text { entertaiment, cul ture, and bustling }\end{array}$ \\
\hline $\begin{array}{l}\text { Q66 Advanced image } \\
\text { inclusive area }\end{array}$ & $\begin{array}{l}\text { Regions that enjoy almost all values of the location area across nature, } \\
\text { function, and impression }\end{array}$ \\
\hline
\end{tabular}

に分散していたが、2015 年にはやや中央に集まって都心 $20 \mathrm{~km}$ 圈付近に 分布する傾向にある。

「CL3 自然価值欠如低イメージ地域」と「CL4 高台永住地域」の両 者は 2000 年から 2015 年にかけて半減しており、都心 $40 \mathrm{~km}$ 圈の中心 部から周縁部にかけて分布している点で、似た傾向をもっている。 ただし前者は渋谷周辺やすずかけ台周辺など、複数の地域でまとま りをもつ傾向が顕著にみられる。

「CL5 歓楽洗練都会地域」は比較的少数であり、2000 年から 2015

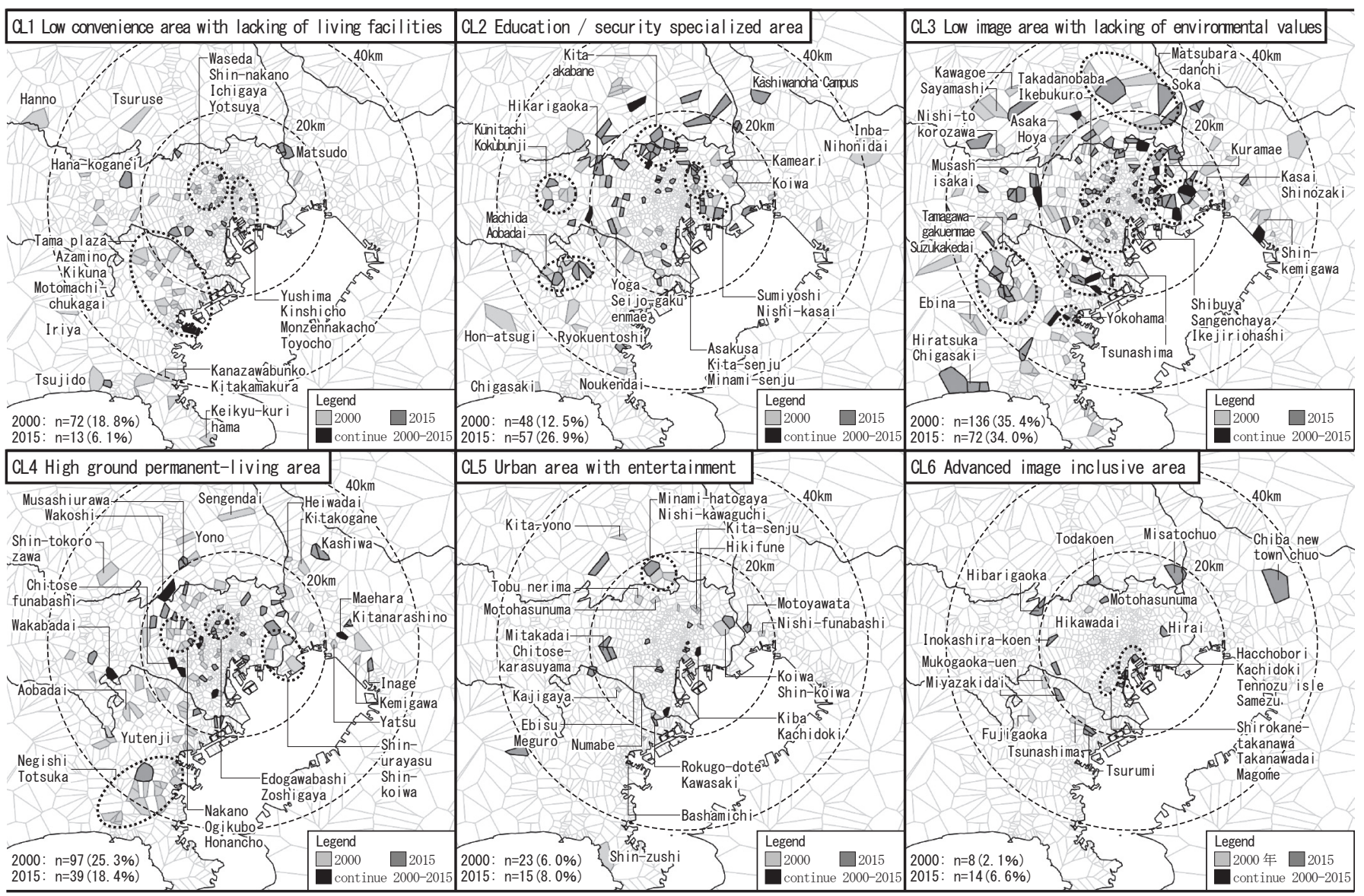

Fig. 13 Distribution of six clusters of regional images 
年にかけて数が減少している。その分布は木場から西船橋など千葉 の一部、馬車道や新逗子などの神奈川の一部など東京湾沿いに散在 しているほか、都心 $20 \mathrm{~km}$ 圈の内陸部にもみられる。

「CL6 高度イメージ包含地域」は最も少数の地域であるが 2015 年 に増加傾向にある。八丁堀・勝どき・天王洲アイルなど東京湾岸沿 いに集積がみられるが、2015 年には千葉ニュータウン中央、井の頭 公園、戸田公園など都心 $20 \mathrm{~km}-40 \mathrm{~km}$ 圈の郊外部にも出現している。

\section{4-3 増加傾向にある 2 つの地域像の内容}

二時点で増加傾向にあった二つの地域像の内容構成の変化を、 Fig. 14, 15 に示した。図では、横軸に 2000 年時点での駅圈単位の平均 該当数を、縦軸に二時点における平均值の差を据えている。

CL2 教育・安心感特化地域では、学校・教育、公園、静寂・頽い などが一貫して多数を占めているなか、買い物や子育て・家族、食事、 安心に関する価值が増加傾向にあり、生活環境に関するイメージが 豊かになりつつあることが把握できる。

CL6 高度イメージ包含地域では、二時代で安定した価值は少なく 増加や減少に転じているものが多い。買い物、公園、学校・教育、 水辺などが増加しつつある半面、利便性、緑、静寂・憩いなどが減 少しており、地域像内部における価值イメージの変容が生じている。

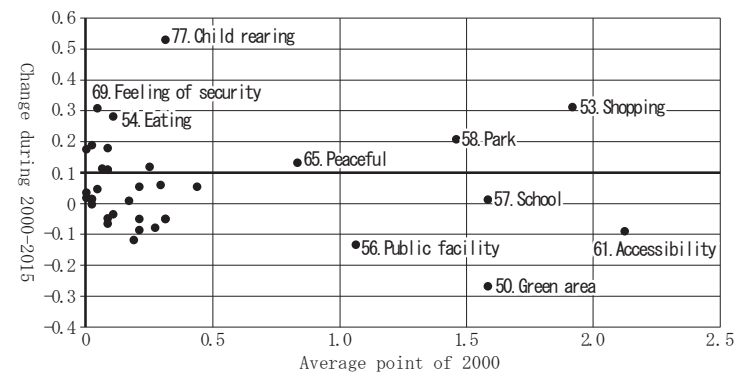

Fig. 14 Change of CL2 Education / security specialized area

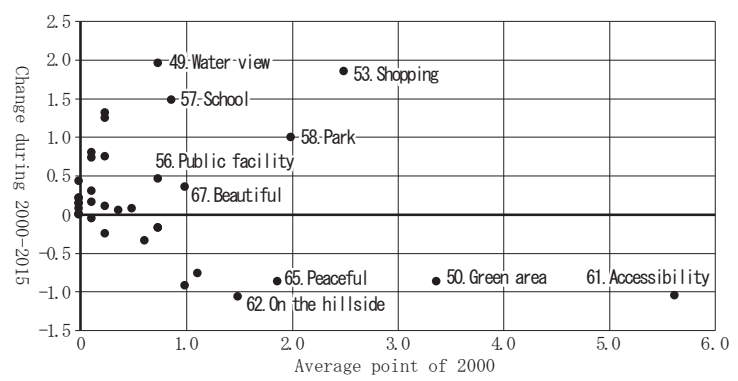

Fig. 15 Change of CL6 Advanced image inclusive area

\section{4-4 地域像の遷移の全体傾向}

次に、地域像の移り変わりに着眼する。2000 年と 2015 年ともに地 域像が読み取れた駅圈は 128 あった。これらを対象に二時点間の地 域類型の対応関係をパスで示した（Fig.16）。図では、10\%未満のパ スを除いて表記してる。

全体をみると、CL3 自然価值欠如低イメージ地域が多く CL1、CL6 が少ないという構成は変わらず、二時点で C L3 が継続している場合 が多いことが把握できる。地域像の遷移に注目すると、CL2 から CL3 への遷移およびCL6 から CL5 の遷移が顕著であることが分かる。

4-5 住宅地価の変化とともに生じる地域像の変容

1) 住宅地価高騰地域と住宅地価下落地域の可視化

土地・建設産業局が公開している地価公示資料のうち住宅地で算 出された地価のみのポイントデータ注 ${ }^{11)}$ を駅圏単位で集計し、駅圏

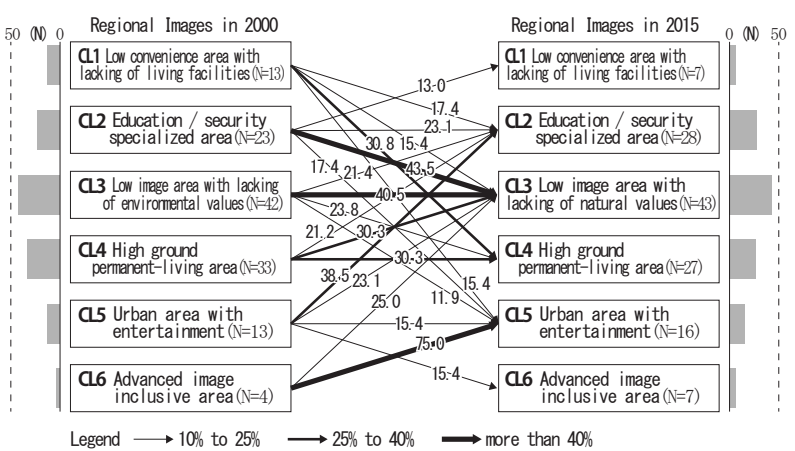

Fig. 16 Transition of regional images 2000-2015

ごとの平均值を算出した。2000 年 1 月 1 日時点、 2015 年 1 月 1 日時 点の双方の平均值の差分を取り、正の值の平均值を「増加平均值」、 負の值の平均值を「減少平均值」とした。これら二つの值を基準に、 住宅地価が相対的に増加・減少している地域を特定し、それぞれ「住 宅地価高騰地域」「住宅地価下落地域」と呼ぶこととする。

分析結果をFig. 17 に示す。住宅地価高騰地域は 65 駅圈に該当し、 東京都区部を中心に分布している。一方住宅地価下落地域は 818 駅 圏に該当し、1 都 3 県の全域に分布していることから、一部の地域を 除いて首都圏のほとんどの地価が減少傾向にあることが分かった。

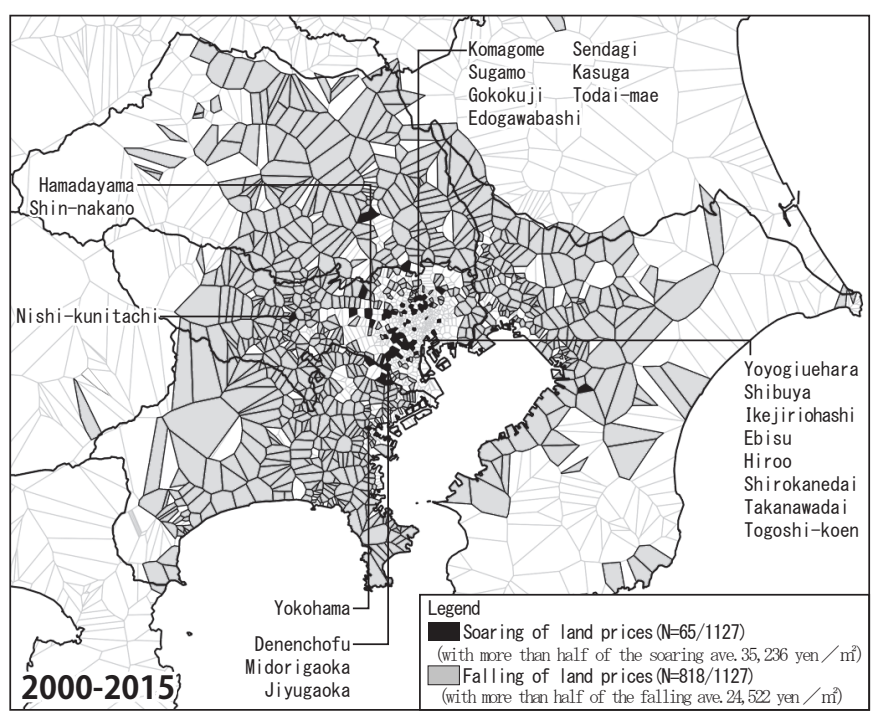

Fig. 17 Areas with soaring / falling of land prices

\section{2）住宅地価高騰地域における地域像の遷移}

抽出された住宅地価高騰地域のうち、二時点の地域像が読み取れ る駅圏は 21 あった。これらの駅圏について、前節と同様の方法で地 域像の遷移を可視化し、Fig. 18 に示した。

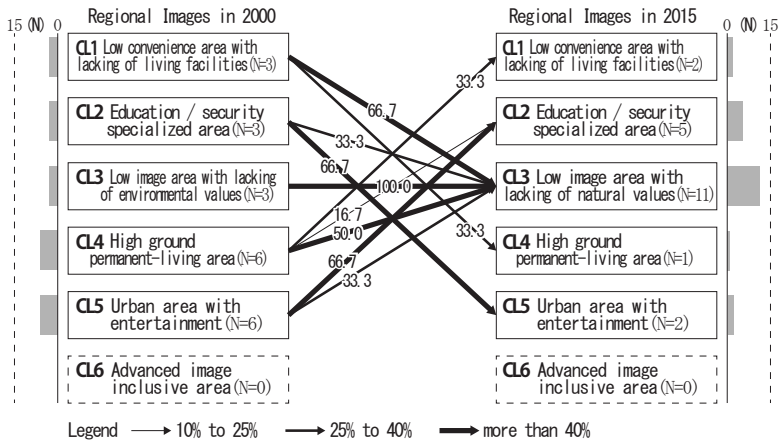

Fig. 18 Transition of regional images in soaring areas 
住宅地価高騰地域の多くは CL3 自然価值欠如低イメージ地域へと 遷移していることが読み取れるが、CL5 歓楽洗練都会地域の一部が CL2 教育・安心感特化地域へと遷移していることや、その逆にCL2 が CL5 へと遷移している様子が見られた。

\section{3）住宅地価下落地域における地域像の遷移}

続いて抽出された住宅地価下落地域のうち、二時点の地域像が読 み取れる 47 駅圈に着眼し、これらの駅圈について同様の方法で地域 像の遷移を可視化し、Fig. 19 に示した。

CL1 生活施設欠如低利便地域から CL5 歓楽洗練都会地域一の遷移 が顕著にみられるのに加えて、CL2 から CL3 への遷移など複数の遷移 がみられる。総じて、CL3への集中が著しい住宅地価高騰地域とは対 照的に、住宅地価下落地域においては多様な地域像の遷移が観察さ れ、結果として該当する地域像の類型の割合の構成も 2000-2015 年 間で変化していることが分かった。

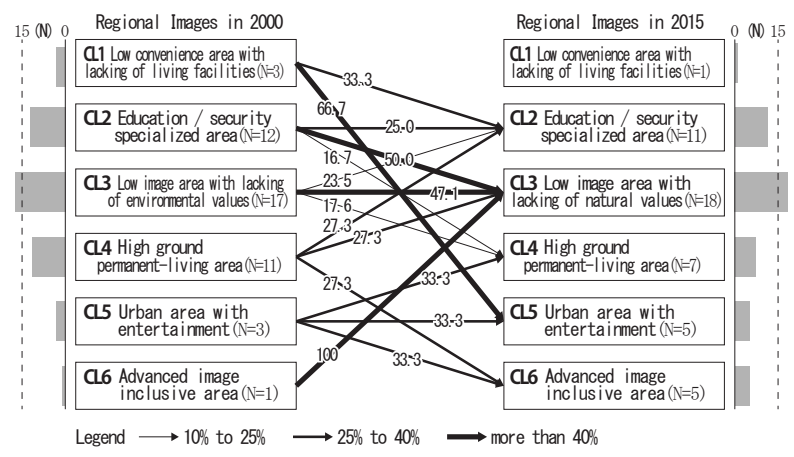

Fig. 19 Transition of regional images in falling areas

\section{4-6 小結 : 住宅地価の変動とともに生じる地域像の遷移}

\section{1）都心回帰下の首都圏における地域像の分布}

本章では第一に地域像が 6 つに類型化され、それらが Fig. 20 のよ うに簡易化できる分布傾向を持つことが明らかになった。すなわち、 CL1, CL3, CL4 の 3 つの地域像が首都圈全域に分布する傾向があるのに 対し、都心 $20 \mathrm{~km}$ 円周部および周縁部にCL2 教育・安心特化地域が、 また周縁部と一部の臨海部を中心にCL5 歓楽洗練都会地域、CL6 高 度イメージ包含地域が分布し、これらはいずれも割合でみる限り近 年増加傾向にあることが把握された。

\begin{tabular}{|c|c|c|}
\hline Center (inside 23-ku part) & Around $20 \mathrm{~km}$ & Periphery $(20 \mathrm{~km}-40 \mathrm{~km})$ \\
\hline $\begin{array}{l}\text { A1 Low convenience area with } \\
\text { lacking of living facilities }\end{array}$ & $\begin{array}{l}\text { C3 Low image area with } \\
\text { lacking of envirormental values }\end{array}$ & $\begin{array}{l}\text { Q4 High ground } \\
\text { permanent-I iving area }\end{array}$ \\
\hline & \multicolumn{2}{|c|}{ Q2 Education / secur ity special ized area } \\
\hline & \multicolumn{2}{|c|}{ a.5 Urban area with entertainment } \\
\hline$\square_{\text {images }}^{\text {Increasing regional }}$ & \multicolumn{2}{|c|}{ C6 Advanced image inclusive area } \\
\hline
\end{tabular}

Fig. 20 Distribution of regional images (summary)

\section{2）住宅地価の変動とともに生じる地域像の遷移}

本章では第二に、地域像の遷移の特徵が明らかになった。 Tab $1 \mathrm{e} 4$ にこれらを再整理する。住宅地価の高騰する地域、下落する地域と もにCL3 自然価值欠如低イメージ地域への地域像の遷移が確認でき、 都心回帰下において CL3 の地域像の偏りが進行しつつあることが 分かった。これに加えて住宅地価高騰地域では CL2 教育・安心感特 化地域と CL5 歓楽洗練都会地域との遷移の関係があり、また住宅地 価下落地域においてはCL1 生活施設欠如低利便地域から CL5 のの遷 移、CL3 から CL2 やCL4 高台永住地域一の遷移が確認できた。
Table4 Change of regional images and Iand prices (summary)

\begin{tabular}{|c|c|c|}
\hline Land price & Transition of regional images & \\
\hline \multirow{3}{*}{ Soaring } & A3 Low ingage area with lacking of enviromental values & no change \\
\hline & $\begin{array}{l}\text { Q1 Low convenience area with lacking of living facilities } \\
\text { a4 High ground permanent-l iving area }\end{array}$ & 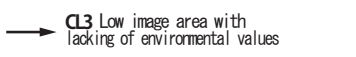 \\
\hline & a2 Education / security specialized area & $\rightleftarrows$ a5 Urban area with entertainment \\
\hline \multirow{4}{*}{ Falling } & Q3 Low ingege area with lacking of enviromental values & no change \\
\hline & $\begin{array}{l}\text { Q2 Education / security special ized area } \\
\text { a6 Advanced image inclusive area }\end{array}$ & 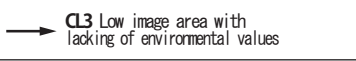 \\
\hline & Q1 Low convenience area with lacking of living facil ities & $\longrightarrow \mathrm{C} 5$ Urban area with entertainment \\
\hline & Q3 Low ingage area with lacking of enviromental values & 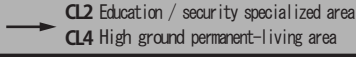 \\
\hline
\end{tabular}

[Notes] The table shows changes with rate over 40\% or changes related to a3 as major changes of regional images. Legend $\square$ Changes towards CL3 and its maintenance $\square$ Changes other than Cl3

\section{5 章 特異な地域像の遷移を遂げる地域の実態}

前章では、都心回帰下における地価の変動とともに生じる地域像 の遷移の中で、CL3 自然価值欠如低イメージ地域への遷移が支配的 であることが確認されたが、これとは異なる遷移を遂げている地域 も存在する。本章ではこれらを特異な地域像の遷移を遂げる地域と して選出し、地域像の変化とともにいかなる物理的環境の変化を遂 げてきたのかを明らかにする。

\section{5-1 特異な地域像の遷移が確認された地域の選出}

Tab1e4 を参照しつつ、特異な地域像の遷移が確認された地域を抽 出した。掲載住宅数が多いものから合計 6 地域を選出したところ、 価格高騰地域では目黒駅（4）・北千住駅周辺（4）、価格下落地域で は入谷駅（4）・松原団地駅（4）・朝霞台駅 (4) ・ 戸田公園駅周辺 (6) が対象となった（数值は掲載住宅数）。

6 地域はそれぞれ固有の特性を持っているため、これらの検討から 地域像変化と物理的な住環境変化との関係について普遍的な論議を 行うことはできない。しかし首都圈内で特異な地域像の遷移が明確 に確認できる地域を検討することによって、少なくとも都心回帰下 の首都圈に生じたイメージ変化の原動力を論じることはできる。

\section{5-2 特異な地域像の遷移が確認された地域の実態}

2000 年、2015 年発行のゼンリン住宅地図を資料に用いて、二時点 の 6 地域の建物変化を可視化した（次頁、Fig.21）。同資料からは、 各年代の建物の用途変化を読み取ることができる。図では、国土交 通省国土政策局国土情報課の示寸各駅の座標を起点に半径 $500 \mathrm{~m}$ の範 囲における主な建物変化を示している。

\section{A) 目黒駅周辺 (CL2 教育・安心感特化地域 $\rightarrow C L 5$ 歓楽洗練都会地域)}

目黒駅周辺では街区レベルの建物変化が複数見られ、更新後の建 物用途も様々である。主なものに映画・録音スタジオや工場から大 規模マンションへの変化、都バス営業所や小規模アパートから超高 層の複合施設への変化、ホテルや専門学校からオフィスビルへの変 化が挙げられる。これらの変化に対して住宅広告においては、以下 のような語りが見られる：

「桜の名所・目黒川。川沿いにはこだわりのショップも多く、街歩きも楽しみ」 「おしやれな店舗やレストランが並ぶファッショナブルな白金台のプラチナ通り」 2015 年「Brillia Towers 目黒の住宅広告より

注)「歓楽洗練都会地域」としての目黒駅周辺の語り

\section{B) 北千住駅周辺 (CL5 歓楽洗練都会地域 $\rightarrow$ CL2 教育 ·安心感特化地域)}

目黒駅とは反対に、北千住駅周辺は CL5 から CL2 への遷移が確認 された地域である。駅周辺では目黒駅周辺と同様に街区レベルの建 物変化が見られるが、更新後の建物用途がオフィスビルではなく、 大学関連施設である点が異なる。最も大きな東京電機大学キャンパ 
スの面積を占めていたのは、たばこ工場とその社宅 15 棟であった。 住宅広告においてはこうした変化は直接的には語られず、J R 常磐 線上野東京ラインの開通などを背景として利便性が強調されている
「駅前にルミネ、マルイ、商店街など多彩な商業施設。荒川緑地や区立図書館も身近 「5 路線が乗り入れる城東エリア最大のターミナルでありながら価格が比較的手頃

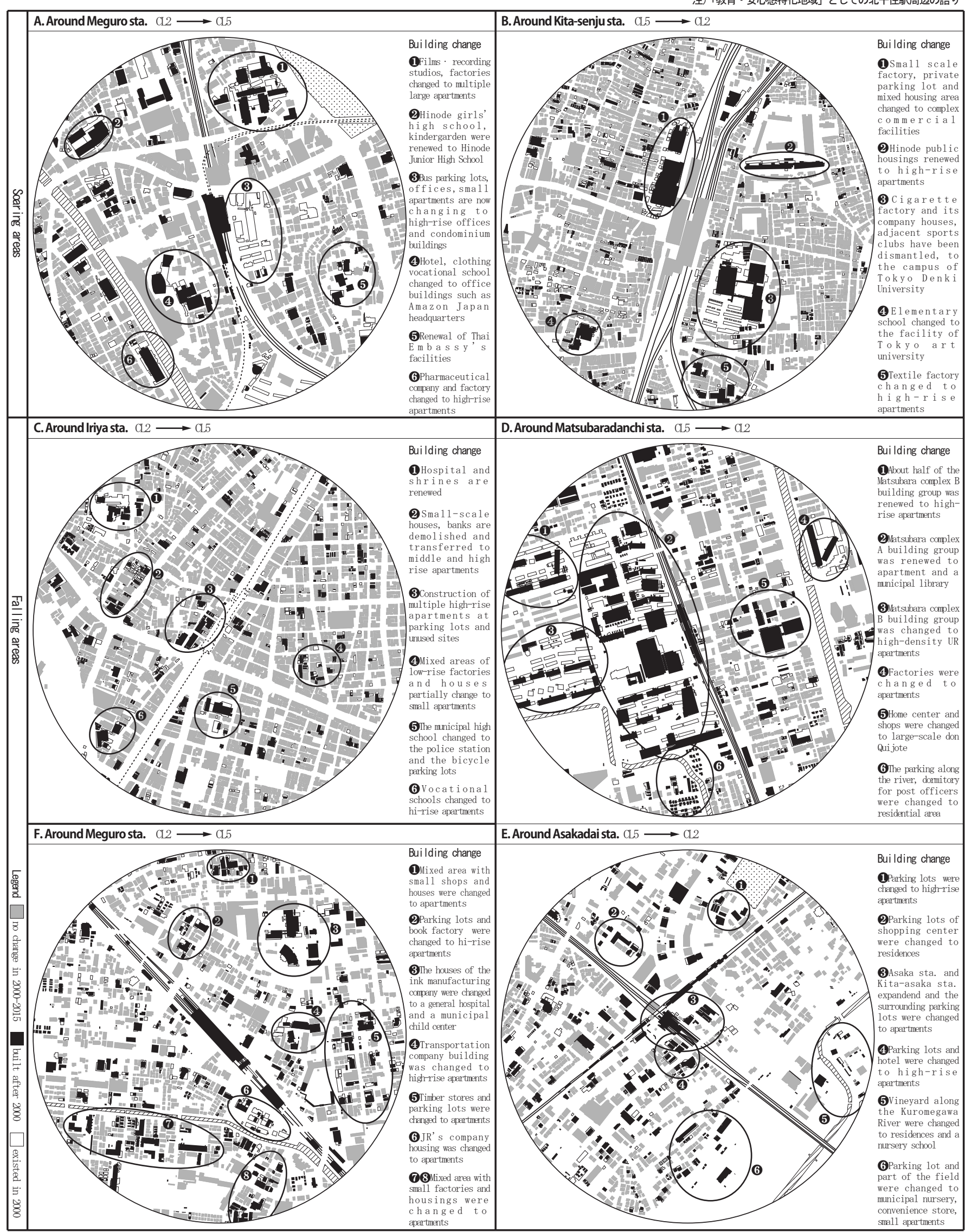

注)「教育・安心感特化地域」としての北千住駅周辺の語り

Fig. 21 Building change in areas with transitions of unique regional images 


\section{C) 入谷駅周辺 (CL1 生活施設欠如低利便地域 $\rightarrow$ CL5 歓楽洗練都会地域)}

入谷駅周辺は低層の工場・住宅の混在地域であり、小規模な建物 更新が分散的に見られる。更新後の建物は高層マンションが多く、 特徵的な用途の出現は見られない。物理的環境とは対照的に住宅広 告においては、上野・浅草を徒歩圈（徒歩 15 分圈内）として強調す ることで、入谷駅周辺の地域像の読み替えが起こっている：

「文化・芸術施設が連なるアカデミックエリア「上野」、四季折々の祭りやグルメ スポットも多い「浅草」。台東区・松ケ谷は、その 2 つ街のちょうど中心」 2015 年「プラウド上野松ケ谷」の住宅広告より

D）松原団地駅周辺、E）朝霞台駅周辺

注) 歓楽洗練都会地域ととてて入容駅周边の語り

\section{(CL3 自然価値欠如低イメージ地域 $\rightarrow C L 2$ 教育・安心感特化地域)}

松原団地駅周辺の大部分は更新されている。駅西側は大規模な団 地が広がっていたが、多くは高層・超高層マンションに変化した。 また南側にあった郵政宿舎は画一的なデザインの戸建て住宅地に変 化している。住宅広告ではこうした大規模な建物更新を強調しつつ、 商業施設等の利便性に関する語りが見られる：

「半世紀以上にわたって育まれた松原団地の「豊かな緑」と「生活利便性」を最大 限に活用し、さらなる快適性を求めた約 54 ha もの地区計画」 2015 年「シティテラス草加松原」の住宅広告より 注)「教育·安心感特化地域」としての松原団地駅周辺の語り

朝霞台駅周辺も松原団地と同様の地域像の遷移が確認されている。 松原団地とは対照的に、小規模で分散的な建物更新が見られる。駅 周辺は駐車場や空き地、烟と住宅が混在していたが、これらの低未 利用地の一部が戸建住宅や小規模マンション、保育園などに変化し ている。住宅広告では、穏やかさと自然が強調され、子育てに適し た街としての地域像を描いている：

「充実の商業・教育施設や穏やかな住環境。公園や自然も残り、子育てファミリー に快適」「保育園徒歩 5 分、小学校徒歩 11 分」

2015 年「アドグランデ朝霞台」の住宅広告より

注)「教育·安心感特化地域」としての朝霞台駅周辺の語り

\section{F) 戸田公園駅周辺（CL3 自然価值欠如低イメージ地域 $\rightarrow C L 6$ 高度イメー ジ包含地域)}

戸田公園駅周辺は CL3 から CL6 への地域像の遷移が確認された地 域である。駅周辺では地区レベルの建物更新を伴う分散的な変化が 見られる。周囲は工場や住宅の混在地域であるが、商店や小規模マ ンション、工場が解体され戸建て住宅や高層マンションに変化した。 また鉄道沿いの J R 社宅、インク製造工場とその社宅が解体される ことで、地区レベルの建物変化を生じている。住宅広告では、埼玉 県で「地域子育て応援タウン」に認定されたことに触れながら、学 校や様々な商業施設の利便性を強調している：

「埼玉県で初めて “地域子育て応援タウン”に認定された「戸田市」」

「ファッション、雑貨、グルメなど 85 の専門店とシネコン…レジャー感覚で楽しめる」 2015 年「ガーラ・レジデンス戸田公園」の住宅広告より

注)「高度イメージ包含地域」としての戸田公園駅周辺の語り

\section{5-3 地域像の変化と物理的住環境との関係}

特異な地域像の遷移が確認された 6 地域では、小規模な工場やマ ンション、戸建て住宅が高層マンションに変化している点が共通し ていた。また大きな面積を占めていた社宅が解体されることで、地 区レベルの建物変化が生じている様子が各所で把握された。

価格高騰地域においては建物用途の変化に特徵があり、商業施設 やオフィスに変化した地域（目黒）と、マンションや大学施設に変
化した地域（北千住）とでそれぞれ地域像の遷移に差が生じている のは明らかである。他方で松原団地を除く価格下落地域においては、 マンションの建設が進むものの建物用途の変化には明らかな差異が 見られないことから、地域像の遷移と物理的環境の変化との間に明 確な関係は指摘できない。本章で扱った地域では、周辺地域の視野 を拡大して享受するような立地地域の読み替え (入谷)、自然環境か ら子育て環境への読み替え (朝霞台)、行政による何らかの認定・後 押し（戸田公園）といった立地地域の認識的変化が強く影響してい ると言える。以上をまとめると Fig. 22 のように整理できる。

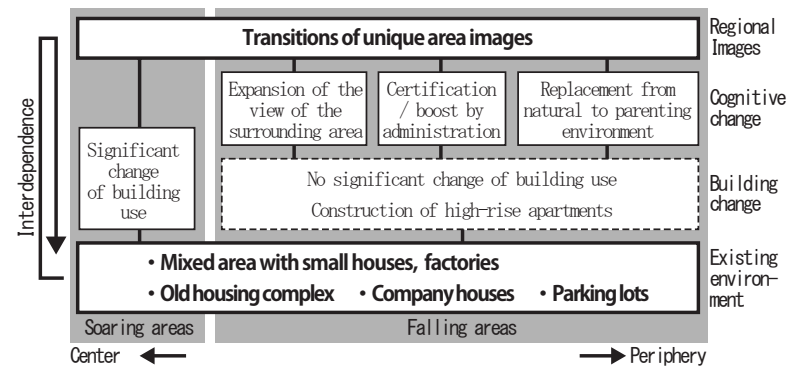

Fig. 22 Relationship between regional images and physical environment

\section{6 章 結言}

\section{6-1 研究の総括}

1）都心回帰下における民間分譲住宅の立地および価値変化（3 章）

人口の都心回帰を担ってきた民間分譲住宅は 2 つ大別できることが 明らかになった。60-89 $\mathrm{m}^{2}$ の広さで 3 千万-6 千万円の価格、15 階建て以 下の住宅（標準民間分譲住宅）と、とそれ以外の多様な住宅（非標準民 間分譲住宅）である。前者は首都圏全域に分布するが、後者は山手線沿 線を中心に放射状の分布構造をもつ。また住環境価值の違いに着目する と、前者は基本的な価值の享受に留まるのに対し、後者はより多様でイ メージ的な価值の享受を謳っている。以上のように都心回帰下の民間分

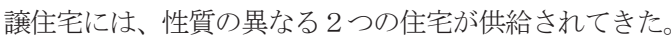

\section{2）住宅地価高騰・下落とともに生じる地域像の遷移}

住宅広告の語りにおける立地地域の価值表現に基づき、地域像が 6 つに類型化され、それぞれ特有の分布傾向を持つことが明らかになっ た。すなわち、CL1 生活施設欠如低利便地域, CL3 自然価值欠如低个 メージ地域, CL4 高台永住地域の 3 つの地域像が首都圏全域に分布す る傾向があるのに対し、都心 $20 \mathrm{~km}$ 円周部および周縁部にCL2 教育・ 安心特化地域が、また周縁部と一部の臨海部を中心に CL5 歓楽洗練 都会地域、CL6 高度イメージ包含地域が分布するというように、地 域像の地理的特性が明らかになった。次に都心回帰下の地域像の遷 移をみると、全体として CL3 自然価值欠如低イメージ地域への遷移 が進行しつつあることが分かった。これらとは異なる地域像の遷移 が確認できた地域を、「特異な地域像の遷移」として抽出した。

\section{3）特異な地域像の遷移を遂げる地域の実態}

特異な地域像の遷移が確認された 6 地域では、小規模な工場やマ ンション、戸建て住宅、団地、社宅などが更新対象となっているこ とが分かった。中でも価格高騰地域においては建物用途の変化に特 徵があり、これに応じて地域像の遷移に差が生じていた。他方で価 格下落地域においては、マンションの建設が進むものの建物用途の 変化には明確な差異が見られず、むしろ周辺地域の視野の拡大、自 然環境から子育て環境への読み替え、行政による何らかの認定・後 押しなどの立地地域の認識的変化が影響していることが把握された。 


\section{6-2 市場化された住宅システムが促す住環境変化}

本研究を通して、2000 年以降の都心回帰の受け血となってきた民 間分譲住宅と、それらの描く地域像の変化が明らかになった (Fig. 23)。 これまで都心回帰下の住宅需要は多様化の一途を辿ってきたことが 指摘されてきたが、本研究では第一に多様な性能を持つ住宅は一部 の鉄道沿線地域にのみ立地していること、第二にその周辺の立地地 域の価值も偏った変化をしつつあることが明らかとなった。したがっ て市場における住環境価值が自然に多様化していくという見通しは、 楽観的であると言わざるを得ない。他方で教育・安心感特化地域、 歓楽洗練都会地域という 2 つの地域像の増加が見られ、これらが今 後の住環境の主要な形式になることも考えられる。今後の変化が格 差化を促進しないよう、長期的に注視する必要がある。

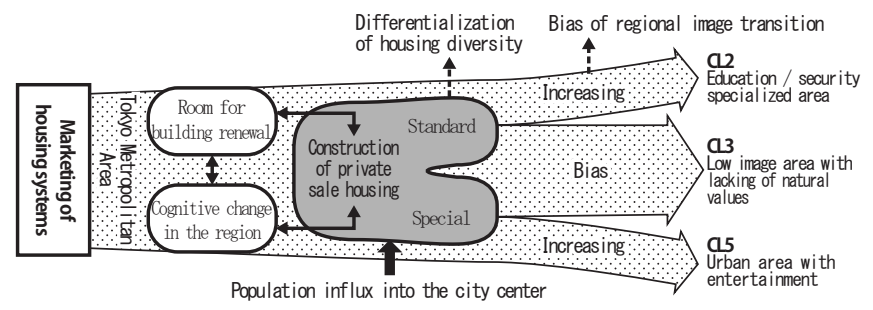

Fig. 23 Changing of Iiving enviroment promoted by marketed housing system

\section{謝辞}

本研究は公益財団法人 大林財団の平成 27 年度奨励研究助成（課 題名：住宅広告の「語り」の地理的分析に基づく東京大都市圏にお ける住環境の価值分布の空間構造、研究代表者：吉江俊）の助成を 受けたものです。記して御礼申し上げます。

注

注 1）これらについては、富田（参考文献1）が詳細な報告を行っている。

注 2）富田がその長年の成果をまとめた近著（参考文献 1) では、21 世紀に再 発見された都心は利便性と生活環境の良さを同時に享受できる場であり、そ こにおいて居住地選好は「消費・余睱関係」と「地縁的・社会的関係」、寸 なわちイメージ的要素と地域的要素が重視される傾向にあると報告している。 また久保（参考文献 4) は、バブル期以来のマンション供給とともに、個人 の価值観やライフスタイルを基準として住宅を選択寸る新たな潮流が生じた ことを指摘している。近年山本里奈（参考文献 5) ら社会学者によって、住 宅のもつ欲望喚起の性質の具体的な検討が、超高層マンションのライフスタ イルなどを例に展開されているのは注目に值する。

注 3）この点については、平山（参考文献 6）が詳細な議論を行っている。

注 4）本稿の住環境論としての位置づけは、筆者の既報（2015）を地理学的に 展開するものとして捉えられる。参考文献 7, 図 1 を参照されたい。

注 5）既報（参考文献 7）2 章にて整理を行っているので、参照されたい。

注 6）資料の選定理由は既報（参考文献 7）の通りである。なお『週刊住宅情報』 は 2002 年に廃刊になっており、これに続き戸建て住宅を取り扱わない『SUUMO 新築マンション』が発行されている。両者の趣旨と掲載内容に差異がないこ とから、本稿ではこれらを資料として扱うこととする。

注 7）ここでは対象住宅のうち価格・平米数・階高の表示されているもの（2000 年 753 件、2015 年 311 件）に限定して分析を行う。

注 8）ほぼすべての住宅が最寄り駅への利便性を重視項目として挙げているこ とから、立地地域の価值表現の集計単位として駅圈が相応しいと考えられる。 外出行動の研究などでは、例えば駅から半径 500m の円を作図して駅圈とす ることも可能であるが、今回は複数の駅圈を分析対象とするため、領域の 重複が無数に生じて分析が困難になることを鑑み、ボロノイ図の作図を行った。

注 9）住宅広告の読み取り・入力を自動化せず行う本研究の方法では、ひとつ の駅圈に対して数件分程度の住宅広告データしか扱うことができない。しか し、ひとつひとつの住宅広告の語りはその周辺地域の価值を一定程度網羅し て語っていることから、これらのデータから駅圈単位の立地地域の価值の 「質」を十分把握できるものと考える。また、ここでは地域ごとの範囲内に 立地するす心゙ての住宅の広告内容の変化を解説するうえで、理解を促すため
に 2015 年時点の地域像を端的に表現する語りを一文ずつ例示した。

注 10）対象となる駅圈は 2000 年で 384 あり、面積は都心から離れるにつれ大 きくなる傾向にある。中央值は $1,533,205.4 \mathrm{~m}^{2}$ (最小面積は $4,941.3 \mathrm{~m}^{2} 、$ 最大面積は $\left.881,510,177.4 \mathrm{~m}^{2}\right)$ であった。また 2015 年の駅圏は 212 あり、 面積の中央值は $1,742,126.2 \mathrm{~m}^{2}$ （最小面積は 48, $304.6 \mathrm{~m}^{2}$ 、最大面積は 253, $\left.645,377.6 \mathrm{~m}^{2}\right)$ であった。

注 11）使用したのは地価公示資料の中でも記録地の用途が「住宅」となってい るもので、 2000 年データで 5978 ポイント、 2015 年データで 3978 ポイントあった。

\section{参考文献}

1) Kazuaki Tomita: Transformation of Central District of Major Cities and Location of Condominiums, Kokon Shoin, 2015 (in Japanese) 富田和暁 : 大都市中心地区の変容とマンション立地, 古今書院, 2015

2) Genko Uchida, Hiroshi Takebayashi, Kenzaburo Takeyama and Fumihiko Maki: The Way to the Housing Industry, Chuo-koron, pp. 214-223, 1968 (in Japanese) 内田元享, 竹林寛, 竹山健三郎, 槇文彦: 住宅産業への道, 中央公論 1968 年 7 月号, pp. 214-223, 1968

3) Mitsuo Takada: Housing in Industrial Society, Kikan Sumairon Vol. 12, p. 13, 1989 (in Japanese)

高田光雄 : 産業社会のなかの住まい一住みごたえの住居論およびソーシャル． 八ウジングの展望, 季刊すまいろん第十二号, p. 13, 1989

4) Rinko Kubo: Housing Research in Tokyo Metropolitan Area, Kokon Shoin, pp.5-9, 2015 (in Japanese)

久保倫子 : 東京大都市圈における八ウジング研究 都心居住と郊外住宅地の 衰退, 古今書院, pp. 5-9, 2015

5) Rina Yamamoto: Generation and Criticality of "My Home" Myth, Iwanami Shoten, 2014 (in Japanese)

山本里奈:マイホーム神話の生成と臨界一住宅社会学の試み, 岩波書店, 2014

6) Yosuke Hirayama: What is the Problem in Housing Policy?, Kobunsha Shinsho, pp. 71-75, 2009 (in Japanese)

平山洋介 : 住宅政策のどこが問題か〈持ち家社会〉の次を展望する, 光文 社新書, pp. 71-75, 2009

7) Shun Yoshie, Haruhiko Goto and Shu Yamamura : Spatiotemporal Transformation of Narrations in Housing Advertisements as the Representations of Values of Living Environment within the Tokyo Metropolitan Area, Journal of Architecture and Planning (Transactions of AIJ) Vol. 80, No. 716, pp. 2231-2241, 2015. 10 (in Japanese) 吉江俊, 後藤春彦, 山村崇 : 首都圏における住環境の価值表現としての住宅広告の 「語り」の时空間的動態, 日本建築学会計画系論文集Vol.80, No.716, pp.2231-2241，2015. 10 8) Shun Yoshie and Haruhiko Goto: Housing Preference Mechanism within Tokyo Metropolitan Area Based on the Resident's Social Characters and Desired for Living Environment, Journal of Architecture and Planning (Transactions of AIJ) Vol. 81, No. 727, pp. 1959-1969, 2016. 9 (in Japanese) 吉江俊, 後藤春彦: 社会属性と住環境欲求からみた首都圈生活者の住宅選好 メカニズム，日本建築学会計画系論文集 Vol.81, No. 727，pp. 1959-1969，2016.9

9) Tomohisa Kurasawa, Akira Soshiroda and Takashi Tsutsumi: A study on the Relationship between the Local Characteristics and the Images of the Tourist Attractions with Townscapes in Travel Magazines, Journal of the City Planning Institute of Japan Vol. 46(3), pp. 1095-1100, 2013 (in Japanese) 倉澤知久, 十代田朗, 津々見崇 : 旅行雑誌にみる町並み観光地のイメージの 変遷と地域特性との関連に関する研究, 都市計画論文集 48(3), pp. 1095-1100, 2013

10) Yuriko Tsuda, Akira Soshiroda and Takashi Tsutsumi: A study on the change of image of hot spring areas in the travel magazine "Tabi", Journal of the City Planning Institute of Japan Vol. 46(3), pp. 607-612, 2011 (in Japanese) 津田夕梨子, 十代田朗, 津々見崇: 雑誌『旅』にみる温泉地に対するイメー ジの変遷に関寸る研究, 都市計画論文集 46(3), pp. 607-612, 2011

11) Toshihiro Osaragi and Kenichi Ogawa: Regional Images Extracted from Spatial Distribution of Building Names, Journal of Architecture and Planning (Transactions of AIJ) Vol.69, No. 576, pp. 101-107, 2004. 2 (in Japanese) 大佛俊泰, 小川健一: 建物名称の空間分布からみた地域イメージの魅力度分 析，日本建築学会計画系論文集 Vol. 69, No. 576, pp. 101-107, 2004.2

12) Masato Momiyama, Akira Soshiroda and Fuyuki Hanyu: A Study on the Commercial and Spatial Characteristics in the Areas in Tokyo of Attracting Visitors from Wide Area through the Urban Information Magazines, City planning review(39), pp. 157-162, 2004 (in Japanese)

籾山真人, 十代田朗, 羽生冬佳ほか : 東京における「都市情報誌」に登場寸る広域集 客型エリア内部の商業的・空間的特性, 別冊 都市計画論文集 (39) pp. 157-162, 2004

13) Mikihisa Yamaguchi and Naohiro Kawasaki: Housing policy in the era of population decline, Kajima Institute of Publishing, 2015 (in Japanese)

山口幹幸, 川崎直宏編: 人口減少時代の住宅政策 戦後 70 年の論点から展 望する，鹿島出版会, 2015 


\title{
SPACIAL STRUCTURE AND TRANSITION OF THE REGIONAL IMAGES \\ WITHIN THE TOKYO METROPOLITAN AREA IN THE ERA OF URBAN CORE REVIVAL
}

\author{
Shun YOSHIE* and Haruhiko GOTO** \\ * Grad. Student, Dept. of Creative Sci. \& Eng., Waseda Univ., M. Arch. \\ ** Prof., Faculty of Creative Sci. \& Eng., Waseda Univ., Dr. Eng.
}

Since the Japanese housing system was marketed at the end of the 20th century, a huge amount of private sale housings were built and became a receiver for the people who returned to the metropolitan area. As more than 20 years have passed since the arrival of the era of urban core revival, it is indispensable to analyze "lifestyle images" seen in the housing market to read changes in the living environment.

The purpose of this paper is to clarify how residential housing has changed the living environment by analyzing expressions used in housing advertisement. There were three investigations and following was obtained:

\section{1) Location and value change of private sale housing under the era of urban core revival}

It became clear that the private sale housing in the era of urban core revival can be roughly divided into two groups. One is a group of houses (named "standard private sale houses") with a price of 30-60 million yen in size of 60-89 square meters and a floor height of 15 floors or less, and the other is a group of houses with various characters (named "special private sale houses"). The former is distributed throughout the metropolitan area, whereas the latter was found to have a radial distribution structure centered around the Yamanote line. Also, paying attention to the difference in living environment value, the former will only enjoy the basic value, while the latter will enjoy more diverse and image-wise value. As mentioned above, two groups with different properties have been supplied to private sale houses to promote population return to central Tokyo.

\section{2) Transition of the regional image caused by soaring and falling of residential land prices}

Based on the value expression of the location area in the housing advertisement, it became clear that the regional images were categorized into six clusters, each having a unique distribution tendency. While three regional images of "CL1: low convenience area with lacking of living facilities", "CL3: low image area with lacking of natural values", and "CL4: high ground permanent-living area" tend to be distributed throughout the metropolitan area,"CL2 education / security specialized area" tend to be distributed around 20km from central Tokyo, and "CL5: urban area with entertainment" and "CL6: advanced image inclusive area" are distributed mainly around the peripheral area and some coastal areas. Next, looking at the transition of regional images under the return to the city center, we found that the transition to "CL3: low image area with lacking of natural values" is mainly progressing in the whole metropolitan area. Areas that achieved transitions of regional images different from these were extracted as "transitions of unique area images" from this analysis.

\section{3) Actual state of the areas that achieved transitions of unique regional images}

In the six areas that achieved "transitions of unique area images", small factories, condominiums, detached houses, apartment complexes, corporate houses were found to be subject to renewal. Among them, in the price rising region, there is a diverse characteristic in the change of building uses, and accordingly there was a difference in the transition of the regional images. On the other hand, in the price falling area, construction of condominiums is progressing but there is no clear difference in the change of building use. Instead of it, it was grasped that cognitive changes in location areas such as expansion of the view of the surrounding area, replacement from the natural environment to the child rearing environment, accreditation and boost by the administration are strongly influenced on the transition of regional images in the price falling area. 